\title{
EFFECT OF KAOLIN FOLIAR ON FRUIT SUNBURN, YIELD AND FRUIT QUALITY OF PERSIMMON TREES
}

\author{
H. M.A. Abo Ogiela \\ Deciduous Fruit Trees Research Department. \\ Horticulture Research Institute, Agriculture Research Center, Giza, Egypt \\ Received: Mar. 8, 2020 \\ Accepted: Jun. 22,2020
}

\begin{abstract}
A field experiment was conducted during 2016 and 2017 seasons at a private orchard situated in Abu El-Matamir destrict, El-Behaira governorate, Egypt, to study the effect of foliar spray of $0,2,3$ and $4 \%$ kaolin, twice or three times in June, July and August on vegetative growth, nutritional status, sunburn percentage, yield and fruit quality of" Costata" persimmon trees. The obtained results showed that, kaolin foliar application at $4 \%$ twice or three times $\left(T_{6}\right.$ and $\left.T_{7}\right)$ considered the best treatments for enhance improvement nutritional status of trees. Moreover, kaolin foliar applications were effective to control fruit sunburn $\%$ as well as reducing severity percentage of sunburned fruits as compared to untreated trees. Also, Kaolin foliar application at three times was decreased leaf and fruit surface temperature especially under 3 and $4 \%$. concentrations. In addition, kaolin treatments increased yield and improved fruit quality in terms of fruit weight, size, height, and diameter as well as fruit firmness. Kaolin foliar spray was raising fruit values of SSC\%, and SSC/acid ratio compared to the control, whereas there is no significant variation among kaolin concentrations on this variables. Therefore, it could be recommended that, spraying kaolin at $4 \%$ three times in summer months, improving increasing gave the best result for improving trees nutritional status, and also it had a positive effect on preventing fruit sunburn damage and increasment yield and fruit quality of " Costata" persimmon trees.
\end{abstract}

Key words: Diospyros kaki, Kaolin, Sunburn, Yield, Fruit quality, solar injury

\section{INTRODUCTION}

Japanese persimmon (Diospyros kaki, L.) belongs to the family Ebenaceae; it has been cultivated in Egypt since 1911, and successfully grown under the Egyptian environmental conditions due to its low chilling requirements Guirguis et al., (2010). So, persimmon increased rapidly and cultivation spreads in many areas in Egypt. However, intense exposure of the persimmon fruit to sunlight can cause sunburn damage looks like large black spots on the fruit skin, which render the fruit unmarketable; and also the incidence of sunburn damage cause high losses in yield and reducing income for growers Schrader et al., (2008) and Lal, Sahu (2017). Therefore, the high susceptibility of fruit to sunburn would suggest the need for external intervention to suppress sunburn in fruit. In this respect, foliar spraying with kaolin is an effective method to reduce sunburn in various fruit crops Aly et al., (2010); Colavita et al., (2011) and Vatandoost et al., (2014). Kaolin particles make films on the leaves and fruits, which reflect sunlight this may be due to lowing the temperature of leaf surface and fruits thereby reducing sunburn and improving fruit quality. Ennab et al., (2017) and Baiea et al., (2018). Kaolin (a clay) is a natural material whose main constituent is kaolinite $\left(\mathrm{Al}_{2} \mathrm{Si}_{2} \mathrm{O}_{5} \mathrm{OH}_{4}\right)$. Kaolin clay trea tments have been successfully applied in different fruit species to minimize fruit sunburn and improve yield and fruit quality Kerns and Wright, (2000); Colavita et al., (2011) and Alvarez et al., (2015). 
Kaolin-based particle films can reduce insect, heat, and ultraviolet stress in horticultural crops because of their ability to modify the microenvironment of the plant canopy as a result of the reflective nature of the particles, Glenn, (2012). Kaolin was significantly effective for reducing apple fruits temperature, the products effectiveness is often expressed in terms of damaged fruit, Alvarez et al., (2015). In this line, Glenn, (2009) mentioned that, kaolin foliar spray on apple tree to reflect sunlight, led to lower the temperature of fruit surface, reducing sun injuries as well as improving yield and fruit quality. Also, Ennab et al. (2017) concluded that, kaolin foliar applications at 3 and $4 \%$ decreased leaf and fruit surface temperature and was more effective to control fruit sunburn $\%$ of "Balady" mandarin trees.

Therefore, the aim of this study is to investigate the effect of kaolin application in different concentrations and times on reducing sunburn and improving yield and fruit quality of persimmon cv Costata .

\section{MATERIALS AND METHODS}

The present study was carried out during 2016 and 2017 seasons on 12 years old Costata persimmon trees (Diospyros kaki, L.) budded on Tarabuls (Diospyrous lotus) rootstock, planted at $4 \times 4$ meter apart in a private orchard situated at Abu El-Matamir destrict, ElBehaira governorate, Egypt (30 $66 \mathrm{~N}$ latitvde and $3006 \mathrm{E}$ longrude). The trees grown in calcareous soil under drip irrigation system; and it received the same cultural practices usually done in this area. The metrological data of the studied period were illustrated in Fig. (1). Forty two trees were selected as uniform as possible in size and load, and arranged in a randomized complete block design, each treatment replicated three times with two trees for each replicate.
Seven treatments were chosen to study the effect of kaolin foliar applications in different concentrations and times on reducing sunburn and improving fruit quality of "Costata" persimmon trees as follows:

$\mathrm{T}_{1}$ Control (spray with tap water only)

$\mathrm{T}_{2}$ Spraying Kaolin at $2 \%$ twice (15 June and 15 July)

$\mathrm{T}_{3}$ Spraying Kaolin at 2\% three times (15 June, 15 July and 15 August)

$\mathrm{T}_{4}$ Spraying Kaolin at 3\% twice (15 June and 15 July)

$\mathrm{T}_{5}$ Spraying Kaolin at 3\% three times (15 June, 15 July and 15 August)

$\mathrm{T}_{6}$ Spraying Kaolin at $4 \%$ twice (15 June and 15 July)

$\mathrm{T}_{7}$ Spraying Kaolin at $4 \%$ three times (15 June, 15 July and 15 August)

\section{The following data was recorded:}

\section{Nutritional status:}

Twenty mature mid-shoot leaves in leat August were sampled to determined chlorophyll a, b and its total by using $\mathrm{N}$, $\mathrm{N}$ dimethyl formamide according to Moran and Porath (1980). The remaining leaf samples were dried at $70^{\circ} \mathrm{C}$ to a constant weight, then ground and digested according to Jackson (1967) by using the mixture of concentrated Sulfuric acid $\left(\mathrm{H}_{2} \mathrm{SO}_{4}\right)+$ per chloric $\left(\mathrm{HClO}_{4}\right)$ (5: 1) to determine the elements $\mathrm{N}, \mathrm{P}, \mathrm{K}, \mathrm{Ca}, \mathrm{Mg}, \mathrm{Fe}, \mathrm{Mn}$ and $\mathrm{Zn}$. Total nitrogen (\%) was determined by using the micro-kjeldahl method as described by Pregl (1945), Phosphorus \% was determined coloremetrically as described by Murphy and Riley (1962), Potassium \% was estimated by using flame photometer as described by Brown and Lillelland (1974), Ca, Mg, Fe, Mn and Zn were assayed with Atomic Absorption spectrophotometer (Unican SP 1900) according to Chapman and Pratt (1961). 


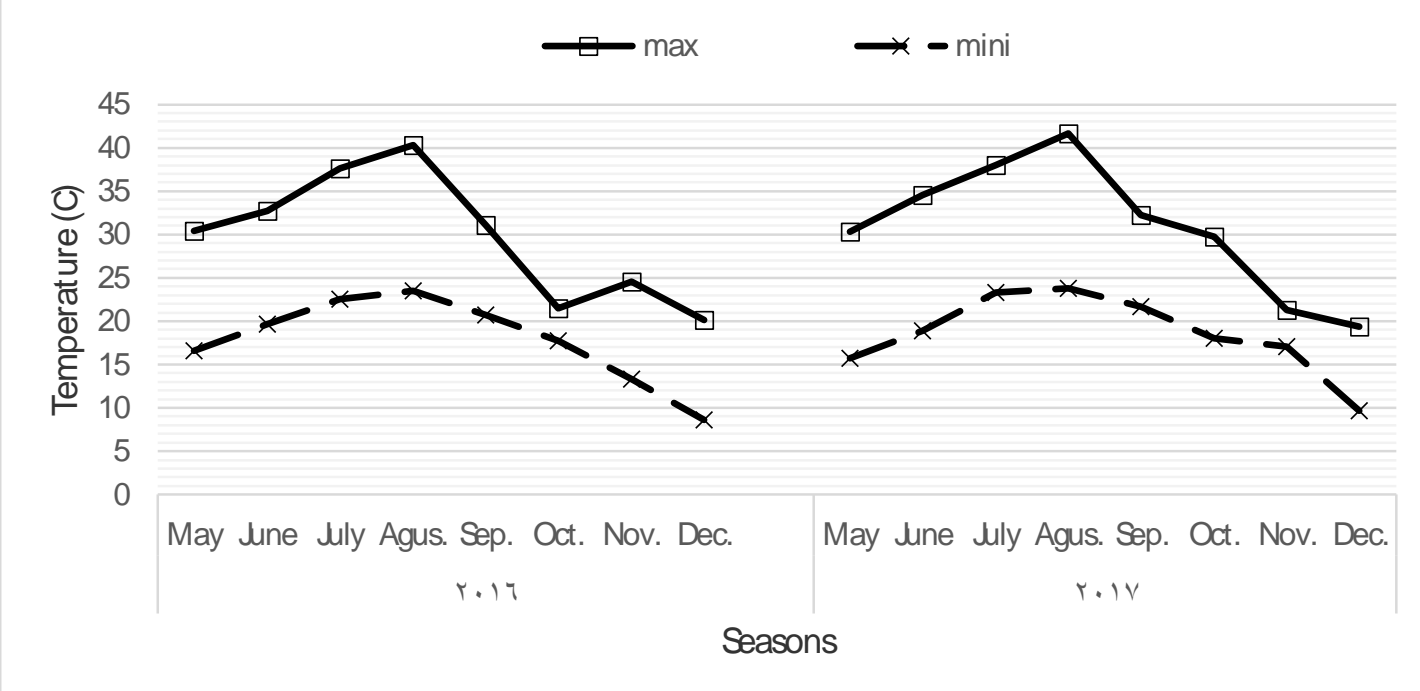

Fig. (1): Mean of maximum and minimum temperature data for Abou El-Matamir area during 2016 and 2017 seasons.

\section{Leaf and fruit surface temperature:}

Leaf and fruit surface temperature were measured on thirty fruit and leaves/tree on a hot months June, July and August on the sunny side of treated and control trees using an infra-red thermometer.

\section{Fruit sunburn percentage:}

Sunburned fruits were counted and the percentage of sunburn was calculated by using the following equation:

Sunburn $\%=\frac{\text { No. of sunburned fruits }}{\text { Total No. of fruits }} \times 100$

\section{Severity (\%) of sunburned fruits:}

At harvest time, all sunburned fruit per tree were divided according to sun injuries to three categories according to black spots area on the fruit skin as (less than $10 \%$ ), medium (10 to $20 \%$ ) and high (more than 20\%).

\section{Yield:}

At harvest time (September $21^{\text {th }}$ and $15^{\text {th }}$ ) in 2016 and 2017 season respectively yield of each replicate was determined as number and weight $(\mathbf{k g})$ of fruits/tree, and total yield as ton/feddan was estimated.

\section{Fruit quality:}

Ten fruits were sampled random from each replicate to determine fruit quality as follow: fruit weight $(\mathrm{g})$, fruit size $\left(\mathrm{cm}^{3}\right)$, fruit height and diameter $(\mathrm{cm})$, and fruit firmness $\left(\mathrm{lb} / \mathrm{inch}^{2}\right)$ were measured at two opposite sides on the equator of each fruit using pressure tester at 5/16 plunger. Total soluble solids (TSS\%) was determined by hand refractometer, total acidity as malic acid and total tannin content in fruit juice were determined according to A.O.A.C., (1990).

\section{Statistical analysis}

The data were statistically analyzed as analysis of variance according to Snedecor and Cochran (1990). Duncan's 
multiple range test Duncan, (1955) at $5 \%$ level was used to compare the mean values.

\section{RESULTS AND DISCUSSION}

\section{Nutritional status:}

\section{Leaf chlorophyll content $\left(\mu \mathrm{g} / \mathrm{cm}^{2}\right)$ :}

Regarding the effect of kaolin foliar application on leaf chlorophyll content of "Costata" persimmon trees, results presented in Table (1) showed that, chlorophyll $a, b$ and its total content were significantly improved with kaolin spraying in both seasons. $T_{6}$ (Kaolin at $4 \%$ twice) and $T_{7}$ (Kaolin at $4 \%$ three times) recorded the highest values of chlorophyll $\mathrm{a}, \mathrm{b}$ and its total contents. On the other hand, $\mathrm{T}_{1}$ (control) recorded the least values in this respect in both seasons. Whereas, $T_{2}, T_{3}, T_{4}$ and $T_{5}$ gave intermediate values in this respect. These results are similar to those of previous studies Lombardini et al., (2005) and Sotelo-Cuitiva et al., (2011).

\section{Leaf mineral content:}

Data presented in Tables (2 and 3 ) revealed that all kaolin treatments significantly increased the leaf marcronutrients (N, P, K, Ca, Mg, Fe, Mn and $\mathrm{Zn}$ ) as compared with control in both seasons. Furthermore, spraying kaolin at $4 \%$ twice or three times $\left(T_{6}\right.$ and $\left.T_{7}\right)$ recorded the highest values of leaf mineral content comparing with control in both seasons. These results are in parallel with those obtained by Stanley, (1998), Schupp et al., (2002) and Aly et al., (2010).

Table (1): Effect of foliar spraying with kaolin on leaf chlorophyll content of Costata persimmon trees during 2016 and 2017 seasons.

\begin{tabular}{|l|c|c|c|c|c|c|}
\hline \multirow{2}{*}{ Treatments } & \multicolumn{6}{c|}{ Leaf chlorophyll content $\left(\mu \mathrm{gg} / \mathrm{cm}^{2}\right):$} \\
\cline { 2 - 7 } & \multicolumn{2}{|c|}{$\mathrm{A}$} & \multicolumn{2}{c|}{$\mathrm{B}$} & \multicolumn{2}{c|}{ Total } \\
\cline { 2 - 7 } & 2016 & 2017 & 2016 & 2017 & 2016 & 2017 \\
\hline $\mathrm{T}_{1}$ (Cont.) & $60.53 \mathrm{~d}$ & $61.35 \mathrm{c}$ & $27.36 \mathrm{c}$ & $27.97 \mathrm{~d}$ & $87.89 \mathrm{c}$ & $89.32 \mathrm{c}$ \\
$\mathrm{T}_{2}$ & $63.81 \mathrm{c}$ & $65.00 \mathrm{~b}$ & $29.29 \mathrm{~b}$ & $30.05 \mathrm{c}$ & $93.10 \mathrm{c}$ & $95.05 \mathrm{~b}$ \\
$\mathrm{~T}_{3}$ & $63.99 \mathrm{c}$ & $65.14 \mathrm{~b}$ & $30.46 \mathrm{a}$ & $30.23 \mathrm{bc}$ & $94.45 \mathrm{~b}$ & $95.37 \mathrm{~b}$ \\
$\mathrm{~T}_{4}$ & $64.51 \mathrm{bc}$ & $64.96 \mathrm{~b}$ & $31.01 \mathrm{a}$ & $31.05 \mathrm{abc}$ & $95.52 \mathrm{~b}$ & $96.01 \mathrm{~b}$ \\
$\mathrm{~T}_{5}$ & $65.46 \mathrm{ab}$ & $65.42 \mathrm{~b}$ & $30.55 \mathrm{a}$ & $31.17 \mathrm{ab}$ & $96.01 \mathrm{~b}$ & $96.59 \mathrm{~b}$ \\
$\mathrm{~T}_{6}$ & $65.37 \mathrm{ab}$ & $67.10 \mathrm{a}$ & $31.08 \mathrm{a}$ & $31.16 \mathrm{ab}$ & $96.45 \mathrm{a}$ & $98.26 \mathrm{a}$ \\
$\mathrm{T}_{7}$ & $65.60 \mathrm{a}$ & $66.66 \mathrm{a}$ & $31.22 \mathrm{a}$ & $31.41 \mathrm{a}$ & $96.82 \mathrm{a}$ & $98.07 \mathrm{a}$ \\
\hline
\end{tabular}

$\mathrm{T}_{1}$ Control (spray with tap water only)

$\mathrm{T}_{2}$ Spraying Kaolin at $2 \%$ twice (15 June and 15 July)

$\mathrm{T}_{3}$ Spraying Kaolin at 2\% three times (15 June, 15 July and 15 August)

$\mathrm{T}_{4}$ Spraying Kaolin at 3\% twice (15 June and 15 July)

$\mathrm{T}_{5}$ Spraying Kaolin at 3\% three times (15 June, 15 July and 15 August)

$\mathrm{T}_{6}$ Spraying Kaolin at 4\% twice (15 June and 15 July)

$\mathrm{T}_{7}$ Spraying Kaolin at $4 \%$ three times (15 June, 15 July and 15 August)

Means followed by different letter are significantly different within columns by Duncan's multiple range test, (DMRT). 
Table (2): Effect of foliar spraying with kaolin on leaf marcronutrients contents (N,P,K and $\mathrm{Ca}$ ) of "Costata" persimmon trees during 2016 and 2017 seasons.

\begin{tabular}{|l|c|c|c|c|c|c|c|c|c|c|}
\hline \multirow{2}{*}{ Treatments } & \multicolumn{8}{c|}{ Marcronutrients \% on D.W t. } \\
\cline { 2 - 10 } & \multicolumn{2}{|c|}{$\mathrm{N}$} & \multicolumn{2}{c|}{$\mathrm{P}$} & \multicolumn{2}{c|}{$\mathrm{K}$} & \multicolumn{2}{c|}{ Ca } & \multicolumn{2}{c|}{ Mg } \\
\cline { 2 - 10 } & 2016 & 2017 & 2016 & 2017 & 2016 & 2017 & 2016 & 2017 & 2016 & 2017 \\
\hline $\mathrm{T}_{1}$ (Cont.) & $1.89 \mathrm{~b}$ & $1.71 \mathrm{~b}$ & $0.159 \mathrm{c}$ & $0.167 \mathrm{c}$ & $1.39 \mathrm{~d}$ & $2.13 \mathrm{a}$ & $1.93 \mathrm{e}$ & $1.21 \mathrm{~b}$ & $0.626 \mathrm{c}$ & $0.613 \mathrm{~b}$ \\
$\mathrm{~T}_{2}$ & $2.18 \mathrm{ab}$ & $2.05 \mathrm{a}$ & $0.171 \mathrm{~b}$ & $0.172 \mathrm{ab}$ & $2.33 \mathrm{bc}$ & $2.38 \mathrm{a}$ & $2.15 \mathrm{c}$ & $2.21 \mathrm{a}$ & $0.633 \mathrm{bc}$ & $0.640 \mathrm{a}$ \\
$\mathrm{T}_{3}$ & $2.20 \mathrm{ab}$ & $2.18 \mathrm{a}$ & $0.171 \mathrm{~b}$ & $0.173 \mathrm{ab}$ & $2.33 \mathrm{bc}$ & $2.22 \mathrm{a}$ & $2.01 \mathrm{~d}$ & $2.33 \mathrm{a}$ & $0.646 \mathrm{~b}$ & $0.643 \mathrm{a}$ \\
$\mathrm{T}_{4}$ & $2.12 \mathrm{~b}$ & $2.07 \mathrm{a}$ & $0.171 \mathrm{~b}$ & $0.174 \mathrm{a}$ & $2.13 \mathrm{c}$ & $2.28 \mathrm{a}$ & $2.64 \mathrm{a}$ & $2.25 \mathrm{a}$ & $0.670 \mathrm{a}$ & $0.643 \mathrm{a}$ \\
$\mathrm{T}_{5}$ & $2.12 \mathrm{~b}$ & $2.06 \mathrm{a}$ & $0.171 \mathrm{~b}$ & $0.174 \mathrm{a}$ & $2.57 \mathrm{ab}$ & $2.31 \mathrm{a}$ & $2.15 \mathrm{c}$ & $2.44 \mathrm{a}$ & $0.666 \mathrm{a}$ & $0.636 \mathrm{a}$ \\
$\mathrm{T}_{6}$ & $2.04 \mathrm{~b}$ & $2.06 \mathrm{a}$ & $0.174 \mathrm{ab}$ & $0.172 \mathrm{~b}$ & $2.59 \mathrm{a}$ & $2.16 \mathrm{a}$ & $2.45 \mathrm{~b}$ & $2.29 \mathrm{a}$ & $0.646 \mathrm{~b}$ & $0.633 \mathrm{a}$ \\
$\mathrm{T}_{7}$ & $2.61 \mathrm{a}$ & $2.09 \mathrm{a}$ & $0.176 \mathrm{a}$ & $0.173 \mathrm{ab}$ & $2.26 \mathrm{c}$ & $2.38 \mathrm{a}$ & $2.68 \mathrm{a}$ & $2.30 \mathrm{a}$ & $0.666 \mathrm{a}$ & $0.646 \mathrm{a}$ \\
\hline
\end{tabular}

$T_{1}$ Control (spray with tap water only)

$T_{2}$ Spraying Kaolin at $2 \%$ twice (15 June and 15 July)

$\mathrm{T}_{3}$ Spraying Kaolin at $2 \%$ three times (15 June, 15 July and 15 August)

$\mathrm{T}_{4}$ Spraying Kaolin at $3 \%$ twice (15 June and 15 July)

$T_{5}$ Spraying Kaolin at $3 \%$ three times (15 June, 15 July and 15 August)

$\mathrm{T}_{6}$ Spraying Kaolin at $4 \%$ twice (15 June and 15 July)

$\mathrm{T}_{7}$ Spraying Kaolin at $4 \%$ three times (15 June, 15 July and 15 August)

Means followed by different letter are significantly different within columns by Duncan's multiple range test (DMRT).

Table (3): Effect of foliar spraying with kaolin on leaf micronutrients (Fe, Mn and $\mathrm{Zn}$ ) of "Costata" persimmon trees during 2016 and 2017 seasons.

\begin{tabular}{|l|c|c|c|c|c|c|}
\hline \multirow{2}{*}{ Treatments } & \multicolumn{5}{|c|}{ Micronutrients (PPm) on D.W t. } \\
\cline { 2 - 7 } & \multicolumn{2}{|c|}{ Fe } & \multicolumn{2}{c|}{ Mn } & \multicolumn{2}{c|}{ Zn } \\
\cline { 2 - 7 } & 2016 & 2017 & 2016 & 2017 & 2016 & 2017 \\
\hline $\mathrm{T}_{1}$ (Cont.) & $75.00 \mathrm{a}$ & $74.51 \mathrm{c}$ & $46.33 \mathrm{e}$ & $45.57 \mathrm{c}$ & $17.36 \mathrm{c}$ & $18.56 \mathrm{~b}$ \\
$\mathrm{~T}_{2}$ & $76.30 \mathrm{a}$ & $78.39 \mathrm{~b}$ & $54.36 \mathrm{bd}$ & $54.36 \mathrm{~b}$ & $18.40 \mathrm{~b}$ & $19.30 \mathrm{~b}$ \\
$\mathrm{~T}_{3}$ & $71.66 \mathrm{a}$ & $78.57 \mathrm{~b}$ & $85.20 \mathrm{a}$ & $62.99 \mathrm{a}$ & $20.05 \mathrm{a}$ & $20.68 \mathrm{a}$ \\
$\mathrm{T}_{4}$ & $72.92 \mathrm{a}$ & $84.53 \mathrm{a}$ & $59.33 \mathrm{~b}$ & $56.34 \mathrm{ab}$ & $20.40 \mathrm{a}$ & $20.54 \mathrm{a}$ \\
$\mathrm{T}_{5}$ & $79.46 \mathrm{a}$ & $82.26 \mathrm{a}$ & $58.50 \mathrm{c}$ & $58.74 \mathrm{ab}$ & $20.40 \mathrm{a}$ & $20.91 \mathrm{a}$ \\
$\mathrm{T}_{6}$ & $79.46 \mathrm{a}$ & $82.03 \mathrm{a}$ & $58.33 \mathrm{c}$ & $58.73 \mathrm{ab}$ & $20.43 \mathrm{a}$ & $21.20 \mathrm{a}$ \\
$\mathrm{T}_{7}$ & $78.03 \mathrm{a}$ & $81.87 \mathrm{a}$ & $58.43 \mathrm{c}$ & $59.20 \mathrm{ab}$ & $20.43 \mathrm{a}$ & $21.26 \mathrm{a}$ \\
\hline
\end{tabular}

$\mathrm{T}_{1}$ Control (spray with tap water only)

$\mathrm{T}_{2}$ Spraying Kaolin at $2 \%$ twice (15 June and 15 July)

$T_{3}$ Spraying Kaolin at 2\% three times (15 June, 15 July and 15 August)

$\mathrm{T}_{4}$ Spraying Kaolin at $3 \%$ twice (15 June and 15 July)

$T_{5}$ Spraying Kaolin at $3 \%$ three times (15 June, 15 July and 15 August)

$\mathrm{T}_{6}$ Spraying Kaolin at $4 \%$ twice (15 June and 15 July)

$\mathrm{T}_{7}$ Spraying Kaolin at $4 \%$ three times (15 June, 15 July and 15 August)

Means followed by different letter are significantly different within columns by Duncan's multiple range test (DMRT). 


\section{Leaf and fruit surface temperature:}

Results presented in Tables (4 and 5) indicated that kaolin treatments significantly decreased leaf and fruit surface temperature compared to the control in both seasons. In this respect, leaf and fruit temperature were decreased by increasing kaolin concentrations from 0 to $4 \%$ in both seasons. Moreover, fruit surface temperature recorded higher values than that recorded on leaf in both seasons. This result was true when kaolin sprayed twice at June and July or three times at June, July and August in both seasons. In addition, kaolin at 3 and $4 \%$ applied twice or three times $\left(T_{4}, T_{5}, T_{6}\right.$ and $T_{7}$ ) recorded the lowest values without significant differences among them in both seasons. On the other hand, the highest temperature recorded of leaf and fruit surface obtained with control trees in both seasons. These results were agreement with those obtained by Gindaba and Wand (2007) on apple,
Colavita et al., (2011) on pear and Chamchaiyaporn et al., (2013) on mango trees.

\section{Fruit sunburn (\%):}

Results presented in Table (6) indicated that, kaolin foliar sprays significantly decreased Fruit sunburn (\%)in both seasons. This reduction was proportional to kaolin concentrations. In this respect, control treatment $\left(T_{1}\right)$ gave the highest percentags $(29.00$ and $29.66 \%$ ) in both seasons, respectively. In the contrast, the lowest percentags of Fruit sunburn (7 and7.10)was recorded in kaolin sprays at $4 \%$ three times $\left(T_{7}\right)$ in both seasons respectively. These results were similar to those obtained by Yazici and Kaynak (2009) on pomegranate, Colavita et al., (2011) on pear and Abd Alla et al., (2013) on mango. In this respect, Melgarejo et al., (2004) found that spraying pomegranate fruits with kaolin decreased percentage of sunburn from $21.9 \%$ to $9.4 \%$.

Table (4): Effect of foliar spraying with kaolin on leaf surface temperature of " Costata " persimmon trees during 2016 and 2017 seasons.

\begin{tabular}{|l|c|c|c|c|c|c|}
\hline \multirow{2}{*}{ Treatments } & \multicolumn{2}{|c|}{ June } & \multicolumn{2}{c|}{ July } & \multicolumn{2}{c|}{ August } \\
\cline { 2 - 7 } & 2016 & 2017 & 2016 & 2017 & 2016 & 2017 \\
\hline $\mathrm{T}_{1}$ (Cont.) & 32.1 & 32.1 & 36.1 & 35.6 & 37.9 & 37.1 \\
$\mathrm{~T}_{2}$ & 29.1 & 30.1 & 31.2 & 28.1 & 34.1 & 34.1 \\
$\mathrm{~T}_{3}$ & 28.0 & 27.5 & 30.1 & 29.0 & 31.2 & 29.1 \\
$\mathrm{~T}_{4}$ & 27.9 & 26.0 & 28.0 & 28.1 & 28.1 & 28.5 \\
$\mathrm{~T}_{5}$ & 26.1 & 25.1 & 27.1 & 25.5 & 29.7 & 26.1 \\
$\mathrm{~T}_{6}$ & 27.3 & 23.8 & 25.1 & 26.3 & 30.1 & 24.3 \\
$\mathrm{~T}_{7}$ & 25.2 & 22.1 & 24.3 & 25.2 & 28.5 & 26.4 \\
\hline
\end{tabular}

$\mathrm{T}_{1}$ Control (spray with tap water only)

$\mathrm{T}_{2}$ Spraying Kaolin at $2 \%$ twice (15 June and 15 July)

$\mathrm{T}_{3}$ Spraying Kaolin at $2 \%$ three times (15 June, 15 July and 15 August)

$\mathrm{T}_{4}$ Spraying Kaolin at $3 \%$ twice (15 June and 15 July)

$\mathrm{T}_{5}$ Spraying Kaolin at 3\% three times (15 June, 15 July and 15 August)

$T_{6}$ Spraying Kaolin at $4 \%$ twice (15 June and 15 July)

$\mathrm{T}_{7}$ Spraying Kaolin at $4 \%$ three times (15 June, 15 July and 15 August)

Means followed by different letter are significantly different within columns by Duncan's multiple range test(DMRT). 
Table (5): Effect of foliar spraying with kaolin on fruit surface temperature of " Costata" persimmon trees during 2016 and 2017 seasons.

\begin{tabular}{|l|l|l|l|l|l|l|}
\hline \multirow{2}{*}{ Treatments } & \multicolumn{2}{|c|}{ June } & \multicolumn{2}{c|}{ July } & \multicolumn{2}{c|}{ August } \\
\cline { 2 - 7 } & 2016 & 2017 & 2016 & 2017 & 2016 & 2017 \\
\hline $\mathrm{T}_{1}$ (Cont.) & 33.1 & 34.1 & 38.4 & 36.3 & 38.0 & 40.5 \\
$\mathrm{~T}_{2}$ & 31.2 & 30.2 & 33.1 & 33.1 & 35.6 & 35.2 \\
$\mathrm{~T}_{3}$ & 30.4 & 30.1 & 32.2 & 30.2 & 33.2 & 33.9 \\
$\mathrm{~T}_{4}$ & 29.1 & 28.5 & 30.1 & 30.1 & 32.5 & 32.5 \\
$\mathrm{~T}_{5}$ & 28.1 & 27.1 & 30.1 & 28.3 & 33.4 & 32.1 \\
$\mathrm{~T}_{6}$ & 30.1 & 26.2 & 28.2 & 30.1 & 32.1 & 31.4 \\
$\mathrm{~T}_{7}$ & 28.1 & 25.1 & 29.4 & 29.2 & 30.4 & 30.6 \\
\hline
\end{tabular}

$\mathrm{T}_{1}$ Control (spray with tap water only)

$T_{2}$ Spraying Kaolin at $2 \%$ twice (15 June and 15 July)

$T_{3}$ Spraying Kaolin at 2\% three times (15 June, 15 July and 15 August)

$\mathrm{T}_{4}$ Spraying Kaolin at $3 \%$ twice (15 June and 15 July)

$T_{5}$ Spraying Kaolin at 3\% three times (15 June, 15 July and 15 August)

$T_{6}$ Spraying Kaolin at $4 \%$ twice (15 June and 15 July)

$\mathrm{T}_{7}$ Spraying Kaolin at $4 \%$ three times (15 June, 15 July and 15 August)

Means followed by different letter are significantly different within columns by Duncan's multiple range test(DMRT).

Table (6): Effect of foliar spraying with kaolin on the percentage of sunburn and sunburn severity percentages of "Costata" persimmon trees during 2016 and 2017 seasons.

\begin{tabular}{|c|c|c|c|c|c|c|c|c|}
\hline \multirow{3}{*}{ Treatments } & \multirow{2}{*}{\multicolumn{2}{|c|}{$\begin{array}{c}\text { Sunburn } \\
\%\end{array}$}} & \multicolumn{6}{|c|}{ Severity $\%$ of sunburned fruit } \\
\hline & & & \multicolumn{3}{|c|}{2016} & \multicolumn{3}{|c|}{2017} \\
\hline & 2016 & 2017 & Light & Medium & High & Light & Medium & High \\
\hline $\mathrm{T}_{1}$ (Cont.) & $29.00 \mathrm{a}$ & $29.66 a$ & $13.33 f$ & $45.00 \mathrm{a}$ & $41.66 a$ & $13.66 \mathrm{~g}$ & $45.00 \mathrm{a}$ & $41.33 a$ \\
\hline $\mathbf{T}_{2}$ & $19.00 \mathrm{~b}$ & $17.66 \mathrm{~b}$ & $44.00 \mathrm{e}$ & $37.33 b$ & $19.66 \mathrm{~b}$ & $43.66 f$ & $37.33 b$ & $19.00 \mathrm{~b}$ \\
\hline $\mathbf{T}_{3}$ & $16.00 \mathrm{c}$ & $15.00 \mathrm{c}$ & $50.66 d$ & $34.00 \mathrm{c}$ & $15.33 \mathrm{c}$ & $349.66 \mathrm{e}$ & $34.00 \mathrm{c}$ & $16.33 b$ \\
\hline $\mathbf{T}_{4}$ & $14.66 \mathrm{~d}$ & $13.66 \mathrm{c}$ & $56.33 \mathrm{c}$ & 31.33d & $11.00 \mathrm{~d}$ & $57.00 \mathrm{~d}$ & $31,33 d$ & $12.00 \mathrm{c}$ \\
\hline$T_{5}$ & $9.66 \mathrm{e}$ & $9.33 d$ & $59.00 \mathrm{~b}$ & $28.66 \mathrm{e}$ & $11.33 d$ & $59.66 c$ & $28.66 e$ & $11.66 \mathrm{c}$ \\
\hline $\mathbf{T}_{6}$ & $8.00 f$ & $68.00 \mathrm{de}$ & $61.00 \mathrm{~b}$ & $28.00 \mathrm{e}$ & $10.00 \mathrm{~d}$ & $67.00 \mathrm{~b}$ & $28.00 \mathrm{e}$ & $10.00 \mathrm{c}$ \\
\hline $\mathbf{T}_{7}$ & $7.00 \mathrm{~g}$ & $7.00 \mathrm{e}$ & $65.66 a$ & $27.33 e$ & $6.00 \mathrm{e}$ & $66.00 \mathrm{a}$ & $27.33 e$ & $6.66 d$ \\
\hline
\end{tabular}

$T_{1}$ Control (spray with tap water only)

$T_{2}$ Spraying Kaolin at $2 \%$ twice (15 June and 15 July)

$T_{3}$ Spraying Kaolin at 2\% three times (15 June, 15 July and 15 August)

$\mathrm{T}_{4}$ Spraying Kaolin at $3 \%$ twice (15 June and 15 July)

$\mathrm{T}_{5}$ Spraying Kaolin at $3 \%$ three times (15 June, 15 July and 15 August)

$T_{6}$ Spraying Kaolin at $4 \%$ twice (15 June and 15 July)

$\mathrm{T}_{7}$ Spraying Kaolin at $4 \%$ three times (15 June, 15 July and 15 August)

Means followed by different letter are significantly different within columns by Duncan's multiple range test (DMRT). 


\section{Severity (\%) of sunburned fruits:}

Data presented in Table (7) cleared that, kaolin foliar spray significantly reduced sun injuries on fruits of in both seasons. Spraying kaolin at 3 and $4 \%$ three times $\left(T_{5}\right.$ and $\left.T_{7}\right)$ reduced sun injuries in light and high categories compared with control and other treatments. The highest sun injuries recorded on sunburned fruits harvested from control treatment $\left(T_{1}\right)$ in medium and high categories in both seasons. These results were in agreement with those obtained by Weerakkody et al., (2010) and Vatandoost et al., (2014). Also, Glenn et al., (2009) and Ennab et al., (2017) revealed that, applications of kaolin at 3 and $6 \%$ every 3 weeks reduced solar injury in "Baldy" mandarin fruits.

It is obvious from data in Tables (4, 5 and 6) that, increasing spraying concentrations with replicated three times had a positive effect on decreasing temperature of leaves and fruits especially at the high concentrations of kaolin (3 and $4 \%$ ) compared to the control. This conclusion agree with the findings of Jifon and Syvertsen (2003) found that leaf temperature of grapefruit trees cv Ruby Red treated with 6\% kaolin was lower than leaves of untreated trees. Also, Melgarejo et al., (2004) using kaolin on pomegranate trees and found a reduction in leaf and fruit temperature as compared to non-treated ones. Furthermore, treatment of foliar spraying kaolin at $4 \%$ three times in summer months showed to be the superior one in reducing sunburn (\%) as compared to control and other treatments in both seasons. These results are in harmony with those obtained by Chabbal et al., (2014) and Hegazi et al., (2014) found that, kaolin applied at 4 and 5\% reduced sunburn \% on "Satsuma" mandarin and pomegranate trees. Such reduction in sunburn percent could be attributed to reduce heat stress and decreasing fruit surface temperature.

Table (7): Effect of foliar spraying with kaolin on yield of "Costata" persimmon trees during 2016 and 2017 seasons.

\begin{tabular}{|l|c|c|c|c|c|c|}
\hline \multirow{2}{*}{ Treatments } & \multicolumn{6}{|c|}{ Yield } \\
\cline { 2 - 7 } & Fruit number/tree & \multicolumn{2}{c|}{ Kg/tree } & \multicolumn{2}{c|}{ ton/feddan } \\
\cline { 2 - 7 } & 2016 & 2017 & 2016 & 2017 & 2016 & 2017 \\
\hline $\mathrm{T}_{1}$ (Cont.) & $227.66 \mathrm{c}$ & $235.00 \mathrm{c}$ & $29.33 \mathrm{~d}$ & $30.33 \mathrm{c}$ & $7.68 \mathrm{~d}$ & $7.93 \mathrm{c}$ \\
$\mathrm{T}_{2}$ & $236.33 \mathrm{~b}$ & $241.66 \mathrm{~b}$ & $33.89 \mathrm{c}$ & $38.11 \mathrm{~b}$ & $8.87 \mathrm{c}$ & $9.98 \mathrm{~b}$ \\
$\mathrm{~T}_{3}$ & $240.66 \mathrm{ab}$ & $243.00 \mathrm{~b}$ & $36.77 \mathrm{~b}$ & $38.24 \mathrm{~b}$ & $9.63 \mathrm{~b}$ & $10.01 \mathrm{~b}$ \\
$\mathrm{~T}_{4}$ & $239.00 \mathrm{~b}$ & $243.33 \mathrm{~b}$ & $38.20 \mathrm{ab}$ & $39.56 \mathrm{ab}$ & $10.00 \mathrm{ab}$ & $10.36 \mathrm{ab}$ \\
$\mathrm{T}_{5}$ & $239.00 \mathrm{~b}$ & $253.66 \mathrm{a}$ & $36.85 \mathrm{~b}$ & $39.96 \mathrm{ab}$ & $9.65 \mathrm{~b}$ & $10.46 \mathrm{ab}$ \\
$\mathrm{T}_{6}$ & $239.33 \mathrm{~b}$ & $250.00 \mathrm{a}$ & $38.32 \mathrm{ab}$ & $41.44 \mathrm{a}$ & $10.03 \mathrm{ab}$ & $10.46 \mathrm{ab}$ \\
$\mathrm{T}_{7}$ & $244.66 \mathrm{a}$ & $252.33 \mathrm{a}$ & $40.18 \mathrm{a}$ & $42.30 \mathrm{a}$ & $10.57 \mathrm{a}$ & $11.06 \mathrm{a}$ \\
\hline
\end{tabular}

$\mathrm{T}_{1}$ Control (spray with tap water only)

$\mathrm{T}_{2}$ Spraying Kaolin at $2 \%$ twice (15 June and 15 July)

$\mathrm{T}_{3}$ Spraying Kaolin at 2\% three times (15 June, 15 July and 15 August)

$\mathrm{T}_{4}$ Spraying Kaolin at $3 \%$ twice (15 June and 15 July)

$\mathrm{T}_{5}$ Spraying Kaolin at 3\% three times (15 June, 15 July and 15 August)

$\mathrm{T}_{6}$ Spraying Kaolin at $4 \%$ twice (15 June and 15 July)

$\mathrm{T}_{7}$ Spraying Kaolin at $4 \%$ three times (15 June, 15 July and 15 August)

Means followed by different letter are significantly different within columns by Duncan's multiple range test (DMRT). 
6. Yield and its components:

Data presented in Table (8) showed that, yield as number of fruits per tree, weight $(\mathrm{kg} / \mathrm{tree})$ and ton/feddan of "Costata" persimmon trees was significantly increased by all kaolin treatments comparing with control during 2016 and 2017 seasons. The highest yield was observed with kaolin foliar application of $4 \%$ twice or three times $\left(T_{6}\right.$ and $T_{7}$ ) and kaolin at $3 \%$ three times $\left(T_{5}\right)$ without significant differences among them in both seasons. However, control and kaolin at $2 \%$ twice $\left(T_{1}\right.$ and $\left.T_{2}\right)$ gave the lowest yield as number of fruits per tree, weight $\mathrm{kg} /$ tree and ton/feddan compared to other treatments in both seasons. These results were in agreement with those obtained by Kerns and Wright (2000) and Lombardini et al., (2005). In this respect, Abdel Ghani et al., (2013) concluded that, kaolin foliar spray at $5 \%$ significantly increased yield as number of fruits per tree or weight $(\mathrm{kg})$ of Aggezi and Picual olive compared to foliar spray with calcium carbonate $(5 \%)$ and tap water.

Table (8): Effect of foliar spraying with kaolin on some physical fruit properties of "Costata" persimmon trees during 2016 and 2017 seasons.

\begin{tabular}{|l|c|c|c|c|c|}
\hline Treatments & $\begin{array}{c}\text { Fruit } \\
\text { weight (g) }\end{array}$ & $\begin{array}{c}\text { Fruit size } \\
\left(\mathrm{cm}^{3}\right)\end{array}$ & $\begin{array}{c}\text { Fruit } \\
\text { height } \\
(\mathrm{cm})\end{array}$ & $\begin{array}{c}\text { Fruit diameter } \\
(\mathrm{cm})\end{array}$ & $\begin{array}{c}\text { Fruit firmness } \\
\left(\mathrm{lb} / \text { inch }^{2}\right)\end{array}$ \\
\hline \multicolumn{5}{|c|}{2016 season } \\
\hline $\mathrm{T}_{1}$ (Cont.) & $120.27 \mathrm{c}$ & $134.3 \mathrm{c}$ & $5.24 \mathrm{~d}$ & $5,68 \mathrm{c}$ & $16.94 \mathrm{~d}$ \\
$\mathrm{~T}_{2}$ & $126.69 \mathrm{~b}$ & $135.5 \mathrm{~b}$ & $6.52 \mathrm{c}$ & $6.17 \mathrm{~b}$ & $18.05 \mathrm{c}$ \\
$\mathrm{T}_{3}$ & $137.76 \mathrm{a}$ & $136.1 \mathrm{~b}$ & $6.76 \mathrm{bc}$ & $7.10 \mathrm{a}$ & $18.32 \mathrm{c}$ \\
$\mathrm{T}_{4}$ & $134.65 \mathrm{a}$ & $137.8 \mathrm{a}$ & $7.23 \mathrm{ab}$ & $7.20 \mathrm{a}$ & $19.15 \mathrm{~b}$ \\
$\mathrm{~T}_{5}$ & $133.64 \mathrm{a}$ & $135,6 \mathrm{~b}$ & $7.36 \mathrm{ab}$ & $7.21 \mathrm{a}$ & $19.84 \mathrm{a}$ \\
$\mathrm{T}_{6}$ & $135.50 \mathrm{a}$ & $137.4 \mathrm{a}$ & $7.56 \mathrm{a}$ & $7.22 \mathrm{a}$ & $19.91 \mathrm{a}$ \\
$\mathrm{T}_{7}$ & $136.26 \mathrm{a}$ & $136.9 \mathrm{a}$ & $7.18 \mathrm{abc}$ & $7.22 \mathrm{a}$ & $20.10 \mathrm{a}$ \\
\hline \multicolumn{7}{|c|}{2017 season } & \\
\hline $\mathrm{T}_{1}$ (Cont.) & $120.09 \mathrm{e}$ & $133.8 \mathrm{c}$ & $5.49 \mathrm{c}$ & $5.45 \mathrm{c}$ & $16.28 \mathrm{c}$ \\
$\mathrm{T}_{2}$ & $124.18 \mathrm{~d}$ & $135.1 \mathrm{~b}$ & $6.35 \mathrm{~b}$ & $6.53 \mathrm{~b}$ & $18.27 \mathrm{~b}$ \\
$\mathrm{~T}_{3}$ & $131.17 \mathrm{c}$ & $137.7 \mathrm{a}$ & $7.41 \mathrm{a}$ & $7.65 \mathrm{a}$ & $18.68 \mathrm{~b}$ \\
$\mathrm{~T}_{4}$ & $135.98 \mathrm{a}$ & $136.0 \mathrm{~b}$ & $7.78 \mathrm{a}$ & $7.25 \mathrm{a}$ & $20.32 \mathrm{a}$ \\
$\mathrm{T}_{5}$ & $134.54 \mathrm{~b}$ & $135.9 \mathrm{~b}$ & $7.42 \mathrm{a}$ & $7.56 \mathrm{a}$ & $21.09 \mathrm{a}$ \\
$\mathrm{T}_{6}$ & $135.64 \mathrm{ab}$ & $137.0 \mathrm{a}$ & $7.34 \mathrm{a}$ & $7.28 \mathrm{a}$ & $20.76 \mathrm{a}$ \\
$\mathrm{T}_{7}$ & $135.58 \mathrm{ab}$ & $137.9 \mathrm{a}$ & $7.34 \mathrm{a}$ & $7.35 \mathrm{a}$ & $20.76 \mathrm{a}$ \\
\hline
\end{tabular}

$\mathrm{T}_{1}$ Control (spray with tap water only)

$T_{2}$ Spraying Kaolin at $2 \%$ twice (15 June and 15 July)

$\mathrm{T}_{3}$ Spraying Kaolin at $2 \%$ three times (15 June, 15 July and 15 August)

$\mathrm{T}_{4}$ Spraying Kaolin at $3 \%$ twice (15 June and 15 July)

$T_{5}$ Spraying Kaolin at $3 \%$ three times (15 June, 15 July and 15 August)

$\mathrm{T}_{6}$ Spraying Kaolin at $4 \%$ twice (15 June and 15 July)

$\mathrm{T}_{7}$ Spraying Kaolin at $4 \%$ three times (15 June, 15 July and 15 August)

Means followed by different letter are significantly different within columns by Duncan's multiple range test (DMRT). 


\section{Fruit quality:}

Data in Table (8) showed a significant differences among treatments in both seasons as for physical fruit properties. fruit weight, fruit size, height, diameter and fruit firmness. Spraying kaolin at $4 \%$ three times $\left(T_{7}\right)$ gave the highest significant values of fruit weight, size, height, diameter and fruit firmness followed by kaolin at $3 \%$ and $2 \%$ sprayed three times $\left(T_{6}\right.$ and $\left.T_{5}\right)$ compared with the control treatment in both seasons. These results are in accordance with those obtained by Palitha et al., (2010), AbdAllah et al., (2013) and Hegazi et al., (2014).

Results presented in Table (9) cleared that, SSC\% and SSC/acid ratio were significantly lower in the control treatment $\left(T_{1}\right)$ than those recorded by all kaolin treatments in both seasons. Kaolin treatments gave approximately the same values of SSC and SSC/acid ratio without significant differences among them in most cases. Mean while, acidity and total tannins was slightly decreased by kaolin treatments without any significant differences among all treatments in both seasons. Generally, kaolin treatments enhanced chemical fruit quality in terms of SSC\%, acidity and SSC/acid ratio as compared with the control, whereas there is no significant variation among kaolin concentrations on chemical fruit quality. Similar results were obtained by Gindaba and Wand (2007) and Chabbal et al., (2014).

Table (9): Effect of foliar spraying with kaolin on some chemical fruit properties of "Costata" persimmon trees during 2016 and 2017 seasons.

\begin{tabular}{|l|c|c|c|c|c|c|c|c|}
\hline \multirow{2}{*}{ Treatments } & \multicolumn{2}{|c|}{$\begin{array}{c}\text { SSC } \\
\text { (\%) }\end{array}$} & \multicolumn{2}{c|}{$\begin{array}{c}\text { Acidity } \\
(\%)\end{array}$} & \multicolumn{2}{c|}{$\begin{array}{c}\text { SSC/acid } \\
\text { (ratio) }\end{array}$} & \multicolumn{2}{c|}{$\begin{array}{c}\text { Total tannins } \\
\text { (mg/100 ml. } \\
\text { juice) }\end{array}$} \\
\cline { 2 - 8 } & 2016 & 2017 & 2016 & 2017 & 2016 & 2017 & 2016 & 2017 \\
\hline $\mathrm{T}_{1}$ (Cont.) & $18.22 \mathrm{c}$ & $19.06 \mathrm{~b}$ & $0.43 \mathrm{a}$ & $0.43 \mathrm{a}$ & $42.37 \mathrm{~b}$ & $43.75 \mathrm{~b}$ & $2.39 \mathrm{a}$ & $2.59 \mathrm{a}$ \\
$\mathrm{T}_{2}$ & $20.08 \mathrm{~b}$ & $20.43 \mathrm{a}$ & $0.38 \mathrm{a}$ & $0.40 \mathrm{a}$ & $52.48 \mathrm{ab}$ & $50.45 \mathrm{ab}$ & $1.72 \mathrm{a}$ & $1.85 \mathrm{a}$ \\
$\mathrm{T}_{3}$ & $20.49 \mathrm{ab}$ & $20.39 \mathrm{a}$ & $0.36 \mathrm{a}$ & $0.40 \mathrm{a}$ & $56.91 \mathrm{ab}$ & $50.65 \mathrm{ab}$ & $1.72 \mathrm{a}$ & $1.93 \mathrm{a}$ \\
$\mathrm{T}_{4}$ & $21.23 \mathrm{a}$ & $20.80 \mathrm{a}$ & $0.36 \mathrm{a}$ & $0.38 \mathrm{a}$ & $59.24 \mathrm{a}$ & $54.56 \mathrm{a}$ & $1.79 \mathrm{a}$ & $1.80 \mathrm{a}$ \\
$\mathrm{T}_{5}$ & $20.90 \mathrm{ab}$ & $20.76 \mathrm{a}$ & $0.38 \mathrm{a}$ & $0.41 \mathrm{a}$ & $55.95 \mathrm{ab}$ & $50.84 \mathrm{ab}$ & $2.02 \mathrm{a}$ & $1.69 \mathrm{a}$ \\
$\mathrm{T}_{6}$ & $20.98 \mathrm{ab}$ & $21.23 \mathrm{a}$ & $0.36 \mathrm{a}$ & $0.39 \mathrm{a}$ & $57.94 \mathrm{ab}$ & $50.45 \mathrm{ab}$ & $1.83 \mathrm{a}$ & $1.60 \mathrm{a}$ \\
$\mathrm{T}_{7}$ & $20.80 \mathrm{ab}$ & $20.76 \mathrm{a}$ & $0.36 \mathrm{a}$ & $0.39 \mathrm{a}$ & $57.61 \mathrm{ab}$ & $52.38 \mathrm{a}$ & $1.70 \mathrm{a}$ & $1.65 \mathrm{a}$ \\
\hline
\end{tabular}

$T_{1}$ Control (spray with tap water only)

$\mathrm{T}_{2}$ Spraying Kaolin at $2 \%$ twice (15 June and 15 July)

$\mathrm{T}_{3}$ Spraying Kaolin at $2 \%$ three times (15 June, 15 July and 15 August)

$\mathrm{T}_{4}$ Spraying Kaolin at $3 \%$ twice (15 June and 15 July)

$T_{5}$ Spraying Kaolin at $3 \%$ three times (15 June, 15 July and 15 August)

$T_{6}$ Spraying Kaolin at $4 \%$ twice (15 June and 15 July)

$\mathrm{T}_{7}$ Spraying Kaolin at $4 \%$ three times (15 June, 15 July and 15 August)

Means followed by different letter are significantly different within columns by Duncan's multiple range test (DMRT). 


\section{CONCLUSION}

In light of this study, spraying kaolin at $4 \%$ twice or three times $\left(T_{6}\right.$ and $\left.T_{7}\right)$ showed to be the best treatments for improving nutritional status and producing maximum yield with high quality of " Costata" persimmon trees, and also had a positive effect on preventing fruit sunburn damage under condition of this study.

\section{REFERENCES}

Abd Allah, A.S.E., E. Abd El-Razek and M.M.S. Saleh (2013). Effect of sunblock materials on preventing sunburn injury of "Keitt" mango fruits. J. Appl. Sci. Res., 9(1): 567 - 571.

Abdel Ghani, N.A., M.A. Galal, M.E. ElSayed, S.M. El-Marsafawy and M.A. Omran (2013). Effect of spraying kaolin and calcium carbonate on the productivity of "Aggezi" and "Picual" olive cvs. J. Plant Production, Mansoura Univ., 4(7): 1035 - 1050.

Alvarez, H.L., C.M. DiBella, G.M. Colavita, P. Oricchio and J. Strachnoy (2015). Comparative effects of kaolin and calcium carbonate on apple fruit surface temperature and leaf net $\mathrm{CO}$ assimilation. Journal of Applied Horticulture, 17(3): $176-180$.

Aly, M., N. Abd El Megeed and R.M. Awad (2010). Reflective particle films affected on sunburn, yield, mineral composition and fruit maturity of 'Anna' apple (Malus domestica) trees. Research Journal of Agriculture and Biological Sciences, 6(1): 84-92.

Association of official Agriculture chemists (1990). Official and Tentative Methods of Analysis, 15th Ed. Washington, D. C., USA.).

Baiea, M.H.M., S.F. EL Gioushy and H.E.M. El Badawy (2018). Efficacy of kaolin and screen duo spraying on fruit sunburn, yield and fruit quality of Keitt mango fruits. J. Plant
Production, Mansoura Univ., 9 (12):1013 - 1020.

Brown, J.D. and O. Lillelland (1974). Rapid determination of potassium and sodium in plant material and soil extracts by flame photometer. Proc. Soc. Hort. Sci., 48: 341-346.

Chabbal, M.D., A.B. Piccoli., G.C. Martinez., M.M. Avanza., S.M. Mazza and V.A. Rodriguez (2014). Kaolin applications to control sunburn in 'Okitsu' mandarin. Cultivos Tropicales, 35(1): 50 - 56.

Chamchaiyaporn, T., K. Jutamanee, P. Kasemsap, P. Vaithanomsat and C. Henpitak (2013). Effects of kaolin clay coating on mango leaf gas exchange, fruit yield and quality. Kasetsart J. (Nat. Sci.) 47:479 - 491.

Chapman, H.D. and P.F. Pratt (1961). Methods of Analysis for Soils, Plant and Waters. Univ. of California, USA,. 169-170pp.

Colavita, G.M., V. Blackhall and S. Valdez (2011). Effect of kaolin particle films on the temperature and solar Injury of pear fruits. Acta Hort. 909:609 - 616.

Duncan, D.B. (1955). Multiple ranges and multiple F-tests. Biometrics, 11:1 - 42.

Ennab, H.A., S.A. El Sayed and M.M.S. Abo El Enin (2017). Effect of kaolin applications on fruit sunburn, yield and fruit quality of Balady mandarin (Citrus reticulata, Blanco). Menoufia J. Plant Prod., 2:129 - 138.

Gindaba, J. and S.J. Wand (2007). Do fruit sunburn control measures affect leaf photosynthetic rate and stomatal conductance in Royal Gala apple? Environmental and Experimental Botany 59:160 - 165.

Glenn, D.M. (2009). Particle film mechanisms of action that reduce the effect of environmental stress in Empire Apple. J. Amer. Soc. Hort. Sci. 134(3):314 - 321. 
Glenn, D.M. (2012). The mechanisms of plant stress mitigation by kaolinbased particle films and applications in horticultural and agricultural crops. HortScience 47(6):710 - 711.

Guirguis, N.S., E.S. Attala, G.B. Mikhael and M.A. Gabr (2010). Effect of sitofex (CPPU) on fruit set, yield and fruit quality of "Costata" persimmon trees. J. Agric. Res. Kafr El-Sheikh Univ., 36(2):206 - 2019.

Hegazi, A., N. R. Samra., E.E.T. El-Baz., B. M. Khalil and M.S. Gawish (2014). Improving fruit quality of Manfalouty and Wonderful pomegranates by using bagging and some spray treatments with gibberellic acid, calcium chloride and kaolin. J. Plant Production, Mansoura Univ., 5 (5): 779 $-792$.

Jackson, M.L. (1967). Soil Chemical Analysis. Prentice Hall of India, New Delhi, p. 498.

Jifon, J. L and J. P. Syvertsen (2003). Kaolin particle film application can increase photosynthesis and water use efficiency of Ruby Red grapefruit leaves. J. Amer. Soc. Hort. Sci., 128:107 - 112 .

Kerns, D.L. and G.C. Wright (2000). Protective and yield enhancement qualities of kaolin on lemons. Citrus and Deciduous Fruit and Nut Research Report (publ. az1178), College of Agriculture and Life Sciences, the University of Arizona, Tucson, Arizona, 85721.

Lal, N. and N. Sahu (2017). Management strategies of sunburn in fruit crops - A review. Int.J. Curr. Microbiol. .Appl. Sci., 6(6): 1126 - 1138.

Lombardini, L., M.K. Harris and D.M. Glenn (2005). Effects of particle film application on leaf gas exchange, water relations, nut yield, and insect populations in mature pecan trees. Hort Science, 40(5):1376 - 1380.
Melgarejo, P., J.J. Martinez, F. Hernandez, R. Martinez-Font, P. Barrows and $\mathbf{A}$. Erez (2004). Kaolin treatment to reduce pomegranate sunburn. Scientia Horticulture, 100(1 - 4): 349 353.

Moran, R. and D. Porath (1980). Chlorophyll determination in intact tissues using $\mathbf{N}, \mathbf{N}$ dimethyl formamide. Plant Physiol., 65:478-479.

Murphy, J. and J.R. Riley (1962). A modified single solution method for the determination of phosphorus in natural water. Anal. Chem., Acta, 27: 31-38.

Palitha, W.J., M. Magdalena and J. Rogers (2010). The effect of maturity, sunburn and application of sunscreen on the internal and external qualities of pomegranate fruit grown in Australia. Scientia Hort., 124: 57 - 61.

Pregl, F. (1945). Quantitative Organic Microanalysis, 4thEd J.A. Churchill, Ltd, London.

Schrader, L.E., J. Sun, J. Zhang, D. Felicetti and J. Tian (2008). Heat and light-induced apple skin disorders: causes and prevention. Acta Hort., 772: 51 - 58.

Schupp, J.R., E. Fallahi and J.K. Chun (2002). Effect of particle film on fruit sunburn maturity and quality of 'Fuji' and 'Honeycrisp' apple. Hort Technology, 12(1): 87 - 90.

Snedecor, G.W. and W.G. Cochran (1990). Statistical methods. 7th Ed. lowa State Univ. Press. Ames., lowa, USA, 593p.

Sotelo-Cuitiva, Y.M., H. Restrepo-Diaz, A. Garcia-Castro, A. Ramirez-Godoy and V.J. Florez-Roncancio (2011). Effect of kaolin film particle applications (Surround WPB) and water deficit on physiological characteristics in rose cut plants (Rose spp L.). American Journal of Plant Sciences, 2:354 358. 
Stanley, D. (1998). Particle films: A new kind of plant protectant. Agricultural Research, 46(11): 16 - 19.

Vatandoost, S., G.H. Davarynejad and A. Tehranifar (2014). Would kaolin particle film avoid sunburn in "Ardestani "pomegranate? Advances in Environmental Biology, 8(12): 607 610.

Weerakkody, P., J. Jobling, M.M. Infante and G. Rogers (2010). The effect of maturity, sunburn and the application of sunscreens on the internal and external qualities of pomegranate fruit grown in Australia. Scientia Horticulturae 124:57 - 61 .

Yazici, K. and L. Kaynak (2009). Effects of kaolin and shading treatments on sunburn on fruit of Hicaznar cultivar of pomegranate (Punica granatum L. cv. Hicaznar). Acta Horticulture, 818:167 - 174. 
تأثير الرش بالكاولين على لفحة الشمس و المحصول و جودة ثمار أشجار الكاكى

\section{هشام محمد عبد الحمبد ابو عجيلة}

قسم اشجار الفاكهة متساقطة الاوراق -معه بحوث البساتين - مركز البحوث الزراعية- الجيزة- مصر

الملخص العربى

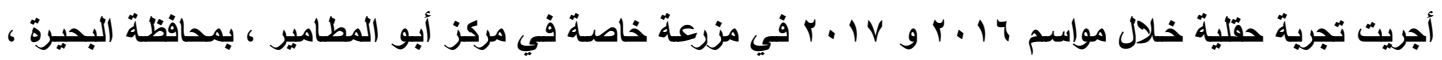

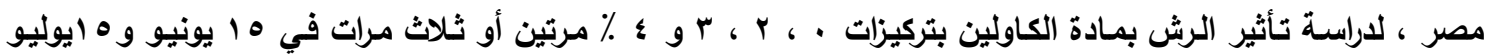

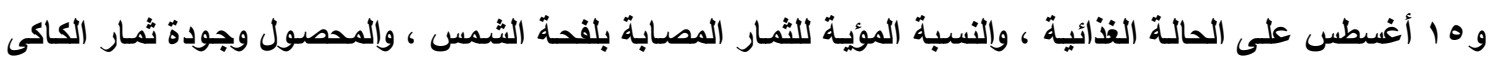
صنف كوستاتا. أظهرت النتائج المتحصل عليها أن رش الكاولين بتركيز ؛ ٪ مرتين أو ثُلاث مـرات والتـي تعتبر أفضل المعاملات لتحسين الحالة الغذائية لأثجار الكاكى. علاوة على ذلك ، كانت معاملات الرش الورقى بالكاولين فعالة في التحكم في في فئي خفض النسبة المئوية للاصابة بلفحة الثمس وكذلك شدة الاصابة مقارنة بالأثجار غير المعاملة. كما أوضحت النتائج

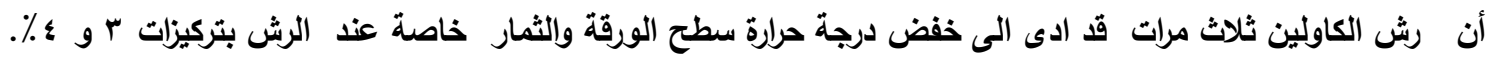

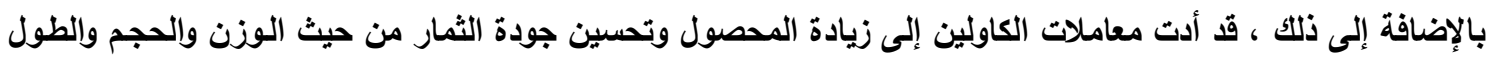

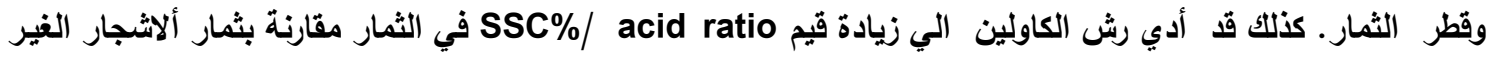

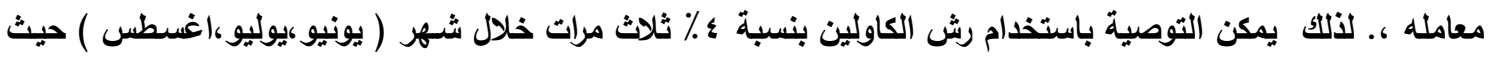

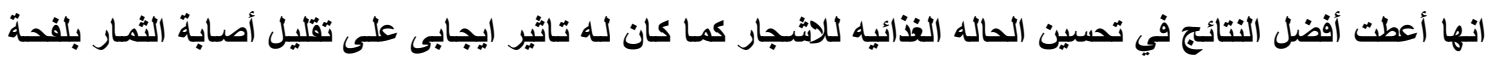
الثمس مع زيادة المحصول وتحسين جودة ثمار اشجار الكاكى صنف "كوستاتا". 
